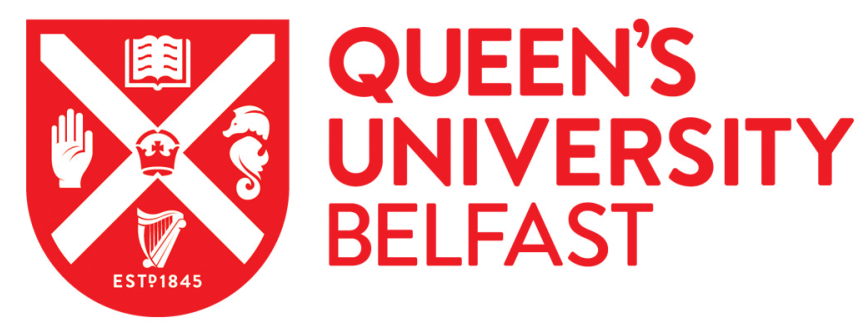

\title{
Diversity of arbuscular mycorrhizal fungi associated with desert ephemerals in plant communities of Junggar Basin, northwest China
}

Shi, Z. Y., Zhang, L. Y., Li, X. L., Feng, G., Tian, C. Y., \& Christie, P. (2007). Diversity of arbuscular mycorrhizal fungi associated with desert ephemerals in plant communities of Junggar Basin, northwest China. Applied Soil Ecology, 35(1), 10-20. https://doi.org/10.1016/j.apsoil.2006.06.002

Published in:

Applied Soil Ecology

Queen's University Belfast - Research Portal:

Link to publication record in Queen's University Belfast Research Portal

\section{General rights}

Copyright for the publications made accessible via the Queen's University Belfast Research Portal is retained by the author(s) and / or other copyright owners and it is a condition of accessing these publications that users recognise and abide by the legal requirements associated with these rights.

Take down policy

The Research Portal is Queen's institutional repository that provides access to Queen's research output. Every effort has been made to ensure that content in the Research Portal does not infringe any person's rights, or applicable UK laws. If you discover content in the Research Portal that you believe breaches copyright or violates any law, please contact openaccess@qub.ac.uk. 


\title{
Diversity of arbuscular mycorrhizal fungi associated with desert ephemerals in plant communities of Junggar Basin, northwest China
}

\author{
Z.Y. Shi ${ }^{\text {a,b }}$, L.Y. Zhang ${ }^{\text {a }}$, X.L. Li ${ }^{\text {b }}$, G. Feng ${ }^{\text {b,* }}$, \\ C.Y. Tian ${ }^{\mathrm{a}}$, P. Christie ${ }^{\mathrm{b}, \mathrm{c}}$ \\ ${ }^{a}$ Xinjiang Institute of Ecology and Geography, Chinese Academy of Sciences, Urumqi 830011, China \\ ${ }^{\mathrm{b}}$ China Agricultural University, College of Resources and Environmental Sciences, Beijing 100094, China \\ ${ }^{\mathrm{c}}$ Queen's University Belfast, Agricultural and Environmental Science Department, Newforge Lane, Belfast BT9 5PX, UK
}

Received 17 August 2005; received in revised form 21 February 2006; accepted 8 June 2006

\begin{abstract}
Colonization by and diversity of arbuscular mycorrhizal (AM) fungi associated with five common ephemerals, Eremopyrum orientale (L.) Jaub. et Spach., Gagea sacculifera Regel., Plantago minuta Pall., Tragopogon kasahstanicus S. Nikit., and Trigonella arcuata C. A. Mey. were investigated in four typical desert plant communities in Junggar Basin, northwest China. All five ephemerals examined were found to be colonized and formed typical arbuscules or vesicles. The proportion of root length colonized ranged from 2 to $85 \%$ with an average of $19 \%$. Spore density in soil near the roots of different ephemerals varied from 1 to 120 spores per $20 \mathrm{ml}$ soil, with an average value of 33 spores. Species richness averaged $8.8 \mathrm{AM}$ fungal species in soil near the roots and ranged from 2 to 21. Fifty-four AM fungal taxa belonging to the genera Acaulospora, Archaeospora, Entrophospora, Glomus and Paraglomus were isolated and identified from soil around the roots. Glomus was the dominant AM fungal genus with a frequency of $100 \%$ and relative abundance of $82.6 \%$. The AM fungal species with the highest frequency of occurrence was Glomus aggregatum with a frequency of $75 \%$. G. microaggregatum was present in the highest relative abundance (16\%). G. sacculifera, P. minuta and T. arcuata formed Arum-type mycorrhizas. Arbuscular mycorrhizal fungi are ubiquitous and Arum-type mycorrhizas are especially prevalent in these important desert communities used for grazing and traditional medicine.
\end{abstract}

(C) 2006 Elsevier B.V. All rights reserved.

Keywords: Arbuscular mycorrhizal fungi; Desert communities; Species richness; Spore density; Relative abundance

\section{Introduction}

Arbuscular mycorrhizal fungi establish broadly distributed potentially symbiotic associations with the majority (80\%) of higher plants (Smith and Read, 1997). The fungi are obligate biotrophs whose growth

\footnotetext{
* Corresponding author. Tel.: +86 1062733885 ; fax: +861062731016.

E-mail address: fenggu@cau.edu.cn (G. Feng).
}

and hyphal development depend on mutualistic association with host plant roots. AM fungi can promote plant establishment by increasing resistance to environmental stresses, enhancing plant nutrient acquisition and improving soil quality (Schreiner et al., 1997; Jeffries and Barea, 2001). Because of the key ecological functions performed by AM associations (Jeffries and Barea, 2001), loss or diminution of mycorrhizal potential in degraded areas may limit the successful re-establishment of native plants (van der Heijden et al., 1998; Requena et al., 2001). van der 
Heijden et al. (1998) showed that belowground diversity of arbuscular mycorrhizal fungi (AMF) may be a major factor contributing to the maintenance of plant biodiversity and to ecosystem functioning.

Ephemeral plants are specially adapted to desert conditions. They remain dormant until a rare rainfall event occurs when they break dormancy and resume rapid growth so that flowering occurs before arid conditions are re-established. Ephemerals usually have a very short epigeous phase with a mean duration of 75.8 days (Wang, 1993), a maximum of 70-90 days and a minimum of only 40-60 days (Zhang, 1985; Mao and Zhang, 1994). Belowground shoot development or seed germination occurs before or at snowmelt and leaf senescence coincides with the onset of the dry season (Mao and Zhang, 1994). Ephemerals are present in arid or semi-arid areas in Junggar Basin in northwest China, and in western and central Asia, the Mediterranean and northern Africa (Mao and Zhang, 1994). Several studies have shown that ephemerals can form arbuscular mycorrhiza. For example, the proportions of root length colonized by AM fungi on the ephemerals Hyacinthoides non-scripta and Erythronium americanum were up to 65 and $75 \%$ in sugar maple forests (DeMars, 1996). Brundrett and Kendrick (1988) found that the ephemerals E. americanum and Allium tricoccum can form AM associations, with root colonization rates of 86 and $83 \%$, respectively. However, these studies were concerned with deciduous forest and there is little information available on the mycorrhizal status of ephemerals in desert ecosystems.

Ephemerals in China are distributed mainly in north Xinjiang, with the eastern edge of Junggar Basin as the easternmost limit (Mao and Zhang, 1994). In Junggar Basin ephemerals emerge in March and resume dormancy between May and June. Ephemeral plants form significant plant synusiae in arid desert ecosystems with typical characteristics of early germination and rapid development during the vegetative growth stage. Ephemerals play a very important role in the stabilization of dunes (Wang et al., 2003) and can decrease the frequency of occurrence and intensity of sandstorms. They are pioneer species during the rehabilitation of deserts following disturbance and are also very a valuable resource for grazing and traditional medicine in early spring. As far as we aware, there have been no published reports on the mycorrhizal status of desert ephemerals. We hypothesise that they might derive some benefit from AM association during their lifecycle, and in the present study we have conducted a preliminary survey of AM fungi associated with ephemerals in four typical desert plant communities of Junggar Basin, Xinjiang Autonomous Region, northwest China.

\section{Materials and methods}

\subsection{Study sites}

Junggar Basin lies at latitude $34^{\circ} 09^{\prime}-49^{\circ} 08^{\prime} \mathrm{N}$ and longitude $73^{\circ} 25^{\prime}-96^{\circ} 24^{\prime} \mathrm{E}$ and forms a scalene triangle between the Altair and Tianshan mountains, extending $1100 \mathrm{~km}$ in length from east to west and up to $800 \mathrm{~km}$ at the broadest part. It covers an area of more than $300,000 \mathrm{~km}^{2}$ in northern Xinjiang Uygur Autonomous Region. The Gurbantunggut Desert, with an area of $48,800 \mathrm{~km}^{2}$ is the second largest desert and the largest fixed or semi-fixed desert in China, and is located in the hinterland of Junggar Basin. Remote from the oceans and surrounded by high mountains, the area has a typical continental climate marked primarily by low precipitation, low specific humidity, long winters and short springs and autumns, high solar radiation and a wide temperature range. The region receives an average annual precipitation of $200 \mathrm{~mm}$ and has a free surface evaporation of 1400-1700 $\mathrm{mm}$. The annual average temperature ranges from -4 to $9{ }^{\circ} \mathrm{C}$ with mean values of -20 to $-15{ }^{\circ} \mathrm{C}$ and $22-26{ }^{\circ} \mathrm{C}$ in January and July, respectively. The frost-free period is about 150 days. Ephemerals are the dominant plants in springtime because they can take the advantage of water resources and temperature conditions in spring to complete their life cycle in about 2 months. In April, May and June, the mean cover of ephemerals reaches 13.9, 40.2 and $14.1 \%$, respectively, with a mean plant height of 10 $20 \mathrm{~cm}$. Four typical desert plant communities were selected for the present study (Table 1).

Annuals with long lifecycles and perennial plants began to sprout during the period of senescence of the ephemerals during the last 10 days of May and the first 10 days of June (Table 1). Artemisia taxa were the dominant plant species in the Artemisia community. Associated plants included Nanophyton crinaceum, Ceratoides sp., Geranum transversale, Iris songorica and Ixiolirion tataricum. $N$. crinaceum also occurred in the undershrub community, together with members of the Polygonaceae and Chenopodiaceae and other ephemerals such as Tulipa iliensis and Tulipa schrenkii. Tamarix sp. and Chenopodiaceae were observed in the Tamarix community and in the Haloxylon community, and Haloxylon persicum and Ephedra distachya were dominant species at the top and the base of the dunes, respectively.

\subsection{Collection of soil and root samples}

Five ephemeral species were studied in Artemisia desert, undershrub desert, Tamarix desert and Haloxylon 
Table 1

Descriptions of the sample sites in the four desert plant communities

\begin{tabular}{|c|c|c|c|c|c|c|}
\hline $\begin{array}{l}\text { Community } \\
\text { type }\end{array}$ & Site & $\begin{array}{l}\text { Elevation } \\
(\mathrm{m})\end{array}$ & Geology & $\begin{array}{l}\text { Annual } \\
\text { precipitation }(\mathrm{mm})\end{array}$ & $\begin{array}{l}\text { Siol } \\
\text { type }\end{array}$ & $\begin{array}{l}\text { Predominant } \\
\text { associated vegetation }\end{array}$ \\
\hline $\begin{array}{l}\text { Artemisia } \\
\text { desert }\end{array}$ & $43^{\circ} 51^{\prime} \mathrm{N} 87^{\circ} 33^{\prime} \mathrm{E}$ & 770 & Foothills & $\geq 200$ & $\begin{array}{l}\text { Brown desert } \\
\text { soils }\end{array}$ & $\begin{array}{l}\text { Artemisia } \mathrm{sp} . \\
\text { Nanophyton crinaceum, } \\
\text { Ceratoides } \text { sp., } \\
\text { Geranum transversale, } \\
\text { Ixiolirion tataricum }\end{array}$ \\
\hline $\begin{array}{l}\text { Undershrub } \\
\text { desert }\end{array}$ & $43^{\circ} 47^{\prime} \mathrm{N} 87^{\circ} 33^{\prime} \mathrm{E}$ & 960 & Zonal low hills & $\geq 200$ & $\begin{array}{l}\text { Brown caliche } \\
\text { soils }\end{array}$ & $\begin{array}{l}\text { N. crinaceum, } \\
\text { Ceratoides } \text { sp., } \\
\text { Artemisia } \text { sp., } \\
\text { Salsola aperta, } \\
\text { S. collina, } \\
\text { Ceratocarpus arenarius, } \\
\text { Anabasis } \mathrm{sp} ., \\
\text { Kochia prostrate, } \\
\text { Tulip } \text { sp. }\end{array}$ \\
\hline $\begin{array}{r}\text { Tamarix } \\
\text { desert }\end{array}$ & $44^{\circ} 07^{\prime} \mathrm{N} 87^{\circ} 49^{\prime} \mathrm{E}$ & 510 & Alluvial plain & $\geq 150$ & $\begin{array}{l}\text { Gray desert } \\
\text { soils }\end{array}$ & $\begin{array}{l}\text { Tamarix sp., Aeluropussp., } \\
\text { Phragmites australis, } \\
\text { Suaeda acuminate, } \\
\text { Halostachys caspica, } \\
\text { Camphorosma monspeliaca }\end{array}$ \\
\hline $\begin{array}{l}\text { Haloxylon } \\
\text { desert }\end{array}$ & $44^{\circ} 32^{\prime} \mathrm{N} 88^{\circ} 16^{\prime} \mathrm{E}$ & $520 \mathrm{~m}$ & $\begin{array}{l}\text { Fixed and } \\
\text { semi-fixed dunes }\end{array}$ & $70-150$ & Aeolian soils & $\begin{array}{l}\text { Haloxylon persicum, } \\
\text { Ephedra distachya, } \\
\text { Seriphidium santolinum, } \\
\text { Calligonum junceum, } \\
\text { Aristide heymannii, } \\
\text { Agriophyllum squarrosum, } \\
\text { Horaninowia ulicina, } \\
\text { Ceratocarpus arenarius }\end{array}$ \\
\hline
\end{tabular}

desert plant communities (Table 2). Soil samples were collected around the roots of five individuals of the same plant species randomly selected at each site. Care was taken during collection of individual plants that roots could be clearly identified as belonging to a particular plant. To ensure that the roots were connected to the study plants, root samples of ephemerals were removed while still connected to the plants. Samples were taken to the laboratory for determination of root colonization. Soil samples (ca. $1000 \mathrm{~g}$ ) associated with the plants removed were collected. The soil samples comprised rhizosphere soil together with soil further from the root surfaces but still likely to have been influenced by the plant roots to some degree. Soil samples were air-dried prior to extraction, counting and identification of spores.

\subsection{Assessment of AM colonization}

Fresh roots (ca. $0.2 \mathrm{~g}$ ) were washed free of soil and cleared in $10 \%(\mathrm{w} / \mathrm{v}) \mathrm{KOH}$ at $90{ }^{\circ} \mathrm{C}$ in a water bath for 20-30 min. The cooled root samples were washed and cut into 0.5-1.0-cm-long segments and stained with $0.5 \%(\mathrm{w} / \mathrm{v})$ acid fuchsin (Biermann and Linderman, 1981). Fifty root fragments from each sample (ca. $1 \mathrm{~cm}$

Table 2

Root and shoot phenology of the plant species investigated

\begin{tabular}{|c|c|c|c|c|c|c|}
\hline \multirow[t]{2}{*}{ Ephemeral plants } & \multicolumn{3}{|c|}{ Period of growth } & \multirow[t]{2}{*}{ Flowering period } & \multicolumn{2}{|c|}{ Period of senescence } \\
\hline & Leaf & Root & Rhizomes & & Leaf & Root \\
\hline Plantago minuta Pall. & $3.18-4.2$ & ES & $\mathrm{N}$ & $4.13-4.21$ & $6.4-6.15$ & $6.4-6.15$ \\
\hline Gagea sacculifera Regel. & ES & LA-ES & LF & $4.1-4.13$ & $4.20-5.3$ & $\mathrm{NP}$ \\
\hline Tragopogon kasahstanicus S. Nikit. & $3.25-4.13$ & NO & NO & $4.28-5.10$ & $6.4-6.15$ & NP \\
\hline Trigonella arcuata C. A. Мey. & $3.28-4.13$ & ES & $\mathrm{N}$ & $5.4-5.13$ & $6.6-6.18$ & $6.6-6.18$ \\
\hline Eremopyrum orientale (L.) Jaub. et Spach. & 4.2 & ES & $\mathrm{N}$ & $5.6-5.14$ & $5.28-6.6$ & $5.28-6.6$ \\
\hline
\end{tabular}

All dates given as month.day. ES, early spring; LF, late autumn; NO, not well observed; N, none; NP, no well-defined period. 
long) were mounted on slides in a polyvinyl alcohol solution (Koske and Tessier, 1983) and examined at 100-400 $\times$ magnification under an Olympus BX50 microscope with an automatic photomicrographic system for the presence of AM fungal structures. The percentage of root length colonized by AM fungal structures was estimated.

\subsection{Recovery and counts of AM fungal spores}

Spores or sporocarps were extracted from $20 \mathrm{~g}$ airdried sub-samples of each soil sample in triplicate by wet sieving followed by flotation-centrifugation in 50\% sucrose (Dalpé, 1993). The finest sieve used was $53 \mu \mathrm{m}$. The spores were collected on a grid patterned $(4 \mathrm{~mm} \times$ $4 \mathrm{~mm}$ ) filter paper, washed three times with distilled water to spread them evenly over the entire grid and counted using a dissecting microscope at $30 \times$ magnification. A sporocarp was counted as one spore. The number of spores is expressed using the mean of three replicates. For observation and identification of spore characters, spores were mounted on glass slides in polyvinyl lactoglycerol (PVLG) and PVLG + Melzer's reagent and then identified to species using current taxonomic criteria (Morton and Redecker, 2001) and information published by INVAM on the Internet (http://invam.caf.wvu.edu).

\subsection{Numbers and distribution of AM fungal spores}

Species richness, spore density, frequency, and relative abundance of AM fungi were expressed as follows: spore density $(\mathrm{SD})=$ number of $\mathrm{AM}$ fungal spores in $20 \mathrm{ml}$ soil; species richness $(\mathrm{SR})=$ number of AM fungal taxa found in $20 \mathrm{ml}$ soil; relative abundance $(\mathrm{RA})=($ number of spores of a species or genus/total spores) $\times 100 \%$; frequency $(F)=$ (number of samples in which the species or genus was observed/total samples) $\times 100 \%$. Species diversity was assessed by the Shannon-Weiner index as follows:

Shannon-Weiner index $=-\operatorname{sum}(\mathrm{P} i \ln [\mathrm{P} i])$,

where $\mathrm{P} i=\mathrm{n} i / N$ and $n i=$ number of individuals in species $I ; N$ is the total number of individuals in all species.

\subsection{Statistical analysis}

The data on the percentage of root length colonized by arbuscular mycorrhiza were normalized by arcsine transformation prior to statistical analysis, and spore density counts and estimates of species richness were subjected to square root transformation. Other data were analyzed without transformation. The root colonization, spore density and AM fungal diversity index results are shown as arithmetic mean values with standard errors. The data were subjected to one-way of analysis of variance and means were compared by least significant difference (LSD) at the 5\% level. The effects of different desert plant communities and host ephemerals, and their interactions with proportion (\%) of root length colonized and spore density of AM fungi were examined by two-way analysis of variance. AM fungal species richness in soils around the roots of different ephemerals in different desert communities was examined using the $\chi^{2}$-test. The statistical tests were applied using SPSS software package version 11.0 developed by SPSS Inc., Chicago, IL 60606, USA.

\section{Results}

\subsection{AM development status}

Typical AM fungal structures were observed in roots of the five dominant ephemeral plants Eremopyrum orientale, Gagea sacculifera, Plantago minuta, Trigonella arcuata and Tragopogon kasahstanicus from the four desert plant communities (Fig. 1). Non-septate hyphae, vesicles and Arum-type arbuscules were observed synchronously in roots of $G$. sacculifera, $P$. minuta and T. arcuata (Fig. $1-1,2,3 ; 10,11,13 ; 12$, 14). Furthermore, appressoria were observed in roots of T. arcuata (Fig. 1 1-15). Non-septate hyphae and vesicles were present in roots of $E$. orientale and $T$. kasahstanicus (Fig. $1-4,5,6,7,8,9$ ).

All five ephemerals were colonized by AM fungi but the degree of colonization varied among plant species and communities (Table 3). The percentage of root length colonized varied from 2 to $85 \%$ with an average of $19 \%$. The degree of colonization was highest in $P$. minuta in Tamarix desert (up to 61\%) and lowest in $E$. orientale in undershrub desert and T. kasahstanicus in Artemisia desert (6\%). Degree of colonization changed with variation in phenology of the host plants. The highest colonization of $P$. minuta occurred during the period of flowering. In $T$. arcuata, the degree of colonization varied among plant communities. Degree of colonization decreased with changes in phenology in Artemisia and Haloxylon communities. In contrast, colonization increased with change in phenology in the undershrub and Tamarix communities. Overall, the highest degree of colonization of $E$. orientale occurred during flowering but there were slight differences in the Haloxylon community. The degree of colonization of $\mathrm{G}$. 
sacculifera decreased with plant development in all four plant communities. Colonization of T. kasahstanicus was enhanced with growth and development in the Artemisia and undershrub communities. In contrast, there was a declining trend in the Tamarix and Haloxylon communities.

\subsection{Genera and species of AM fungi}

A total of 54 taxa representing five genera of AM fungi were isolated and identified (Table 4). Of these, twelve species belonged to Acaulospora, 39 to Glomus, and 1 each to Archaeospora, Entrophospora and Paraglomus.

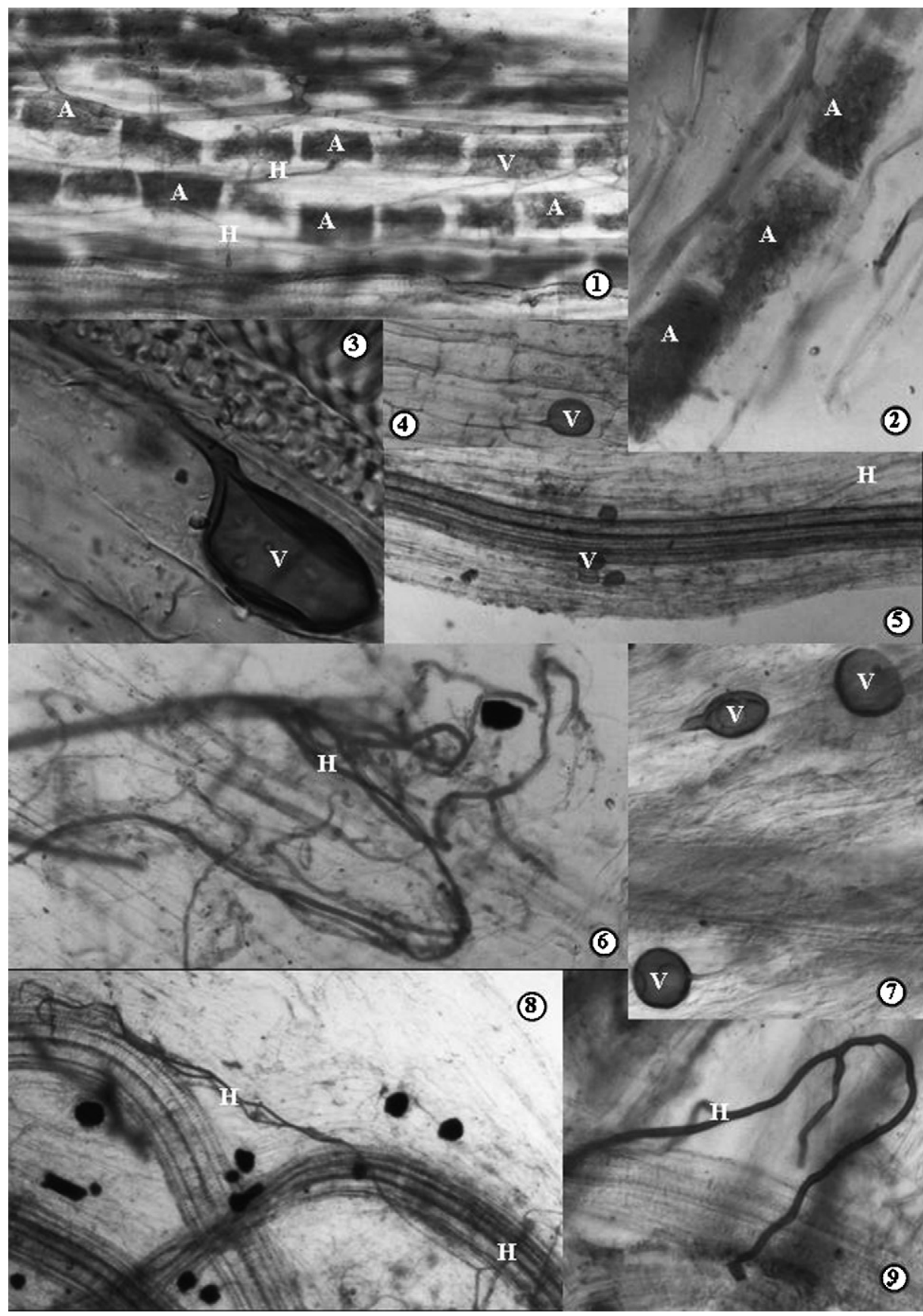

Fig. 1. AM fungal structures in roots of ephemeral plants Plantago minuta: $1(300 \times), 2(600 \times), 3(600 \times) ;$ Tragopogon kasahstanicu: $4(150 \times) ; 5$ $(60 \times), 6(300 \times)$; Eremopyrum orientale: $7(300 \times), 8(150 \times), 9(300 \times)$; Gagea sacculifera: $10(300 \times), 11(300 \times), 13(300 \times)$; Trigonella arcuata: $12(600 \times), 14(300 \times), 15(300 \times)$. A: arbuscule, V: vesicle, H: hyphae, Ap: appressoria. 


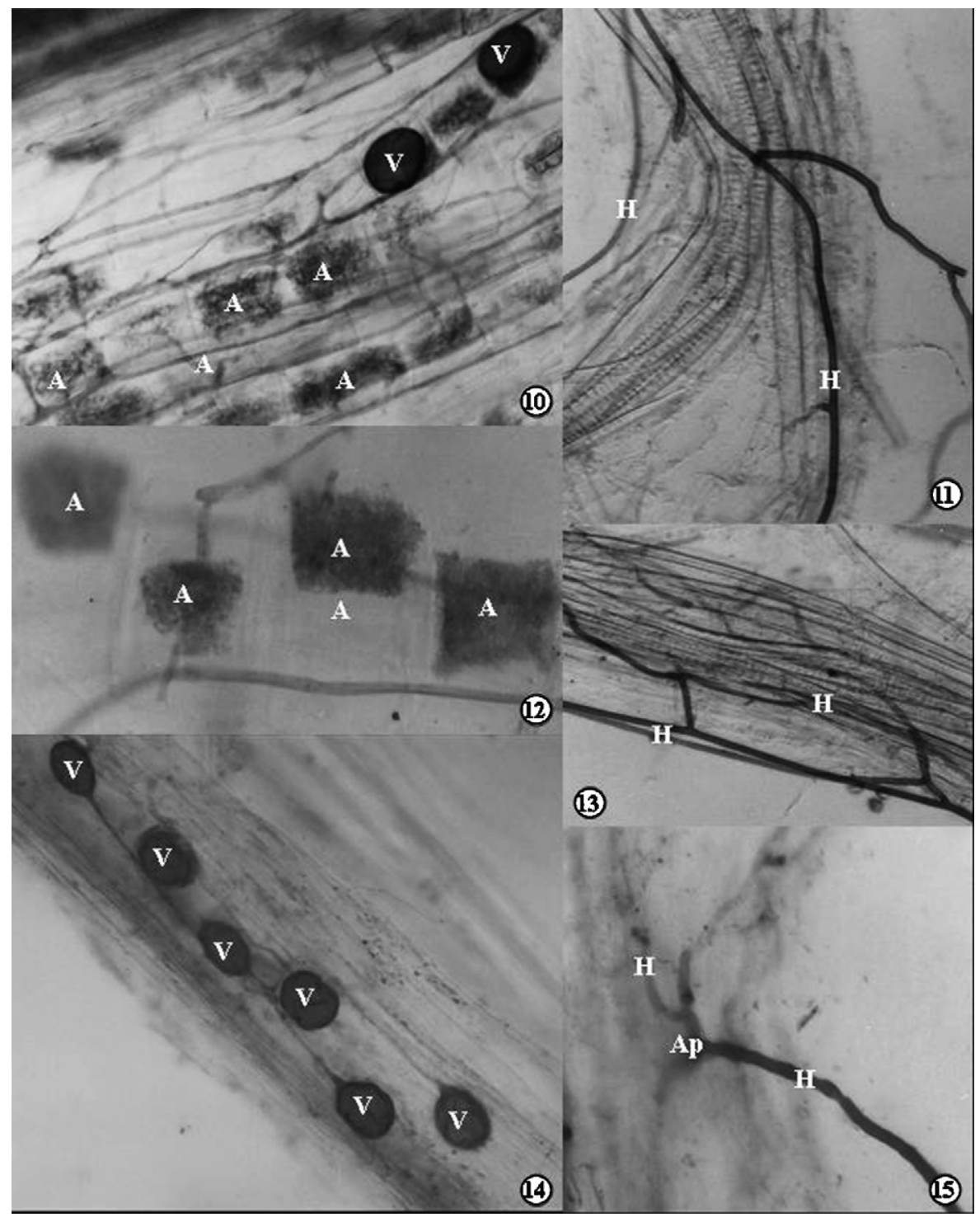

Fig. 1. (Continued).

\subsection{Spore density of $A M$ fungi}

The spore densities in soil associated with the five ephemerals ranged from 1 to 120 per $20 \mathrm{~g}$ soil, with an average of $33 \pm 2.8$. Significant differences were observed among soils collected from the different plant communities. Spore densities of AM fungi in soil associated with roots of $T$. kasahstanicus in the Artemisia community were highest $(55 \pm 11.8)$ and the lowest $(4 \pm 1.7)$ spore densities were observed in the soil near the roots of $P$. minuta in the Haloxylon community (Table 5). Spore densities in the soils from Artemisia and undershrub communities were higher than in Tamarix and Haloxylon communities. No correlation was found between phenology and spore density.

\subsection{Species richness of AM fungi}

The species richness of AM fungi ranged from 2 to 21 with an average value of 8.8 (Table 6). Among the four communities, species richness of AM fungi in the Artemisia (12.0) and undershrub (9.4) communities was higher than in the Tamarix (6.4) and Haloxylon (7.4) communities. The highest species richness was observed in T. kasahstanicus, with a mean value of 12 , while the lowest appeared in T. arcuata, with a mean value of 5.8 . 
Table 3

Proportion (\%) of root length colonized by AM fungi on different dates

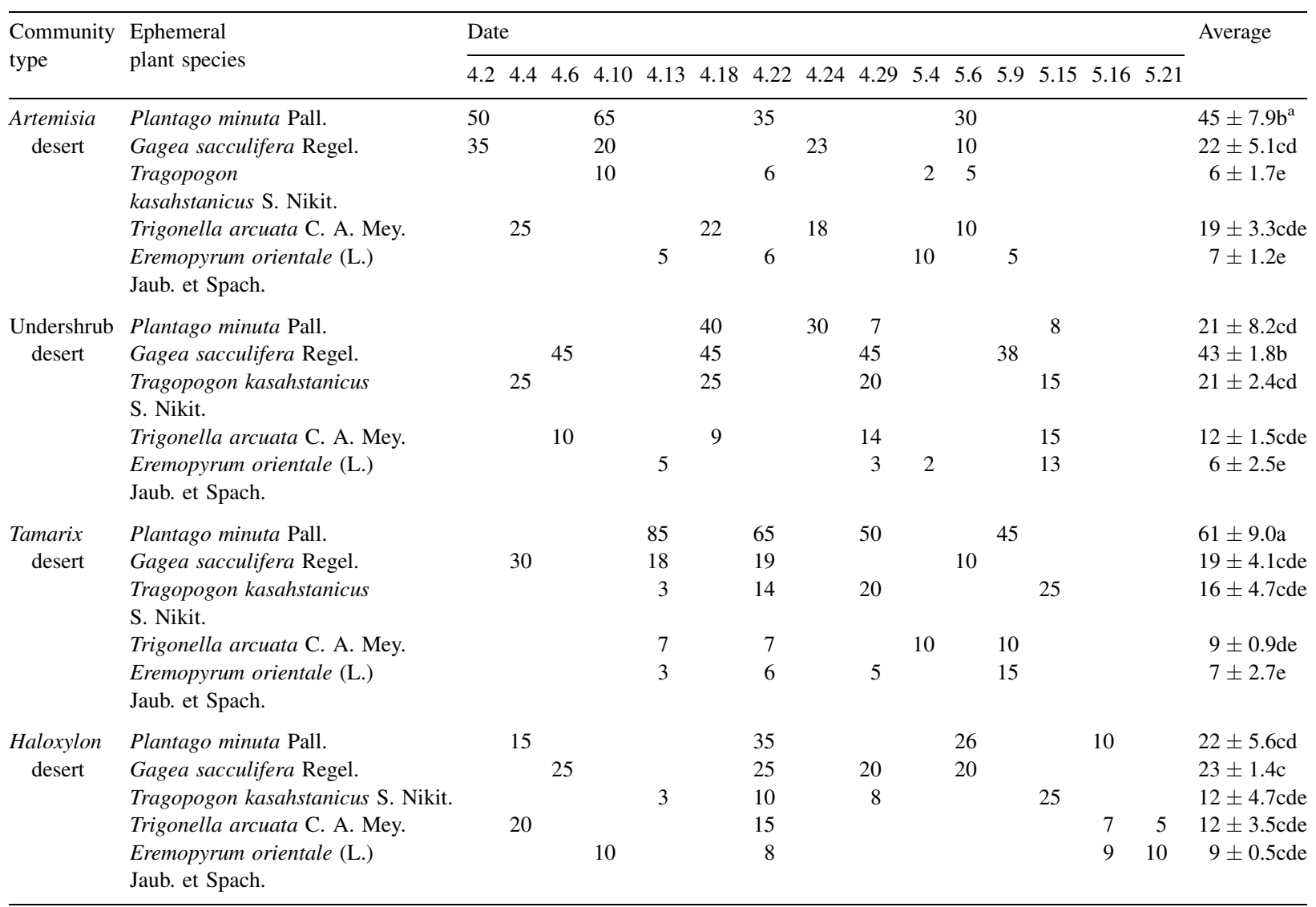

The data were arcsine-transformed prior to statistical analysis. By ANOVA, community type: $F$ value $2.47 \mathrm{~ns}$; host plant species: $F$ value $28.51^{*}$; community type $\times$ host plant species: $F$ value $6.57^{*}$ ( $\left({ }^{*} P<0.05\right.$; ns, not significant).

${ }^{a}$ Mean values followed by the same letter are not significant by LSD at the $5 \%$ level.

\subsection{Relative abundance and frequency of AM fungi}

Frequencies and relative abundances of the genera and some dominant species of AM fungi are presented in Table 7. Spores of the genus Glomus were the most numerous in both frequency and relative abundance. Fungi belonging to the genus Glomus were isolated from all samples. The most frequent $(75 \%)$ and most abundant species (16.3\%) were Glomus aggregatum and G. microaggregatum.

Table 4

Genera and species of AM fungi in soils associated with the roots of ephemeral plants in four desert plant communities in Junggar Basin

\begin{tabular}{ll}
\hline Genus & Species \\
\hline Acaulospora & A. appendicola, A. australe, A. delicate, A. denticulate, A. elegans, A. excavate, A. foveata, A. gdanskensis, \\
Archaeospora & A. longula, A. rehmii, A. tuberculata, A. sp1 \\
Entrophospora & A. leptoticha \\
Glomus & E. infrequens \\
& G. aggregatum, G. albidum, G. canadense, G. chimonobambusa, G. citricolum, G. claroideum, G. clarum, \\
& G. constrictum, G. convolutum, G. deserticola, G. diaphanum, G. dolichosporum, G. dominikii, G. etunicatum, \\
& G. gibbosum, G. glomerulatum, G. hoi, G. invermaium, G. lacteum, G. macrocarpum, G. microaggregatum, \\
& G. mortonii, G. mosseae, G. nanolumen, G. pallidum, G. reticulatum, G. rubiformis, G. spurcum, \\
G. teune, G. liquidambaris, G. halonatum, G. sp1, G. sp2 \\
Paraglomus $(1)$
\end{tabular}


Table 5

Spore density of AM fungi in the soils associated with the roots of different ephemerals in four desert community types

\begin{tabular}{|c|c|c|c|c|c|c|c|c|c|c|c|c|c|c|c|c|c|}
\hline \multirow{2}{*}{$\begin{array}{l}\text { Community } \\
\text { type }\end{array}$} & \multirow{2}{*}{$\begin{array}{l}\text { Ephemeral } \\
\text { plant species }\end{array}$} & \multicolumn{15}{|c|}{ Date } & \multirow[t]{2}{*}{ Average } \\
\hline & & 4.2 & 4.4 & 4.6 & 4.1 & 4.13 & 4.18 & 4.22 & 4.24 & 4.29 & 5.4 & 5.6 & 5.9 & 5.15 & 5.16 & 5.21 & \\
\hline $\begin{array}{l}\text { Artemisia } \\
\text { desert }\end{array}$ & $\begin{array}{l}\text { Plantago minuta Pall. } \\
\text { Gagea sacculifera } \text { Regel. } \\
\text { Tragopogon kasahstanicus S. Nikit. } \\
\text { Trigonella arcuata } \text { C. A. Mey. } \\
\text { Eremopyrum } \\
\text { orientale (L.) Jaub. et Spach. }\end{array}$ & $\begin{array}{l}51 \\
24\end{array}$ & 46 & & $\begin{array}{l}48 \\
43 \\
59\end{array}$ & 48 & 42 & $\begin{array}{l}45 \\
34 \\
50\end{array}$ & $\begin{array}{l}68 \\
37\end{array}$ & & $\begin{array}{l}86 \\
45\end{array}$ & $\begin{array}{l}36 \\
38 \\
39 \\
41\end{array}$ & 41 & & & & $\begin{array}{l}45 \pm 3.2 \mathrm{ab}^{\mathrm{a}} \\
43 \pm 9.2 \mathrm{ab} \\
55 \pm 11.8 \mathrm{a} \\
42 \pm 1.8 \mathrm{ab} \\
46 \pm 2.0 \mathrm{ab}\end{array}$ \\
\hline $\begin{array}{c}\text { Undershrub } \\
\text { desert }\end{array}$ & $\begin{array}{l}\text { Plantago minuta Pall. } \\
\text { Gagea sacculifera } \text { Regel. } \\
\text { Tragopogon kasahstanicus S. Nikit. } \\
\text { Trigonella arcuata C. A. Mey. } \\
\text { Eremopyrum } \\
\text { orientale (L.) Jaub. et Spach. }\end{array}$ & & 120 & $\begin{array}{r}103 \\
45\end{array}$ & & 12 & $\begin{array}{r}58 \\
9 \\
9 \\
37\end{array}$ & & 36 & $\begin{array}{l}40 \\
24 \\
24 \\
29 \\
60\end{array}$ & 21 & & 28 & $\begin{array}{l}64 \\
43 \\
35 \\
32\end{array}$ & & & $\begin{array}{l}50 \pm 6.8 \mathrm{ab} \\
41 \pm 21.1 \mathrm{ab} \\
49 \pm 24.7 \mathrm{ab} \\
37 \pm 3.3 \mathrm{ab} \\
31 \pm 10.4 \mathrm{abc}\end{array}$ \\
\hline $\begin{array}{r}\text { Tamarix } \\
\text { desert }\end{array}$ & $\begin{array}{l}\text { Plantago minuta Pall. } \\
\text { Gagea sacculifera } \text { Regel. } \\
\text { Tragopogon kasahstanicus S. Nikit. } \\
\text { Trigonella arcuata C. A. Mey. } \\
\text { Eremopyrum } \\
\text { orientale (L.) Jaub. et Spach. }\end{array}$ & & 13 & & & $\begin{array}{r}25 \\
8 \\
6 \\
12 \\
23\end{array}$ & & $\begin{array}{r}32 \\
56 \\
9 \\
76 \\
70\end{array}$ & & $\begin{array}{l}39 \\
6 \\
5\end{array}$ & 4 & 19 & $\begin{array}{l}43 \\
27 \\
28\end{array}$ & 18 & & & $\begin{array}{l}35 \pm 4.0 \mathrm{ab} \\
24 \pm 10.9 \mathrm{bc} \\
10 \pm 2.8 \mathrm{~cd} \\
30 \pm 16.1 \mathrm{abc} \\
32 \pm 13.8 \mathrm{abc}\end{array}$ \\
\hline $\begin{array}{c}\text { Haloxylon } \\
\text { desert }\end{array}$ & $\begin{array}{l}\text { Plantago minuta Pall. } \\
\text { Gagea sacculifera } \text { Regel. } \\
\text { Tragopogon kasahstanicus S. Nikit. } \\
\text { Trigonella arcuata } \text { C. A. Mey. } \\
\text { Eremopyrum } \\
\text { orientale (L.) Jaub. et Spach. }\end{array}$ & & 2 & 14 & 115 & 10 & & $\begin{array}{r}8 \\
6 \\
4 \\
41 \\
16\end{array}$ & & $\begin{array}{l}9 \\
8\end{array}$ & & $\begin{array}{r}6 \\
11\end{array}$ & & 15 & $\begin{array}{r}43 \\
3\end{array}$ & $\begin{array}{l}29 \\
29\end{array}$ & $\begin{aligned} 4 & \pm 1.7 \mathrm{~d} \\
10 & \pm 1.7 \mathrm{~cd} \\
9 & \pm 2.3 \mathrm{~cd} \\
30 & \pm 8.3 \mathrm{abc} \\
41 & \pm 25.3 \mathrm{abc}\end{aligned}$ \\
\hline
\end{tabular}

The data were square root-transformed by prior to statistical analysis. By ANOVA, community type: $F$ value $10.48^{*}$; host plant species: $F$ value 0.60 ns; community type $\times$ host plant species: $F$ value $1.31 \mathrm{~ns}\left({ }^{*} P<0.05\right.$; ns, not significant).

a Mean values followed by the same letter are not significant by LSD at the $5 \%$ level.

\subsection{Species diversity of AM fungi in different communities}

The AM fungal diversity differed in the different plant communities (Fig. 2). The highest species diversity, up to 2.86, was present in the undershrub community, and the species diversity was lowest (2.16) in the Haloxylon community.

Table 6

AM fungal species richness in soils associated with the roots of different ephemeral plants at four different desert plant communities

\begin{tabular}{lcccc}
\hline $\begin{array}{l}\text { Ephemeral } \\
\text { species }\end{array}$ & $\begin{array}{l}\text { Artemisia } \\
\text { desert }\end{array}$ & $\begin{array}{l}\text { Undershrub } \\
\text { desert }\end{array}$ & $\begin{array}{l}\text { Tamarix } \\
\text { desert }\end{array}$ & $\begin{array}{l}\text { Haloxylon } \\
\text { desert }\end{array}$ \\
\hline $\begin{array}{l}\text { Plantago minuta } \\
\text { Gagea sacculifera }\end{array}$ & 11 & 7 & 11 & 11 \\
$\begin{array}{l}\text { Tragopogon } \\
\quad \text { kasahstanicus }\end{array}$ & 16 & 15 & 11 & 5 \\
$\begin{array}{l}\text { Trigonella arcuata } \\
\text { Eremopyrum }\end{array}$ & 12 & 21 & 4 & 7 \\
$\quad 13$ & 2 & 2 & 7 \\
orientale & & & 4 & 7
\end{tabular}

$\chi^{2}$-Test: $\chi^{2}=7.571$, d.f. $=19, P=0.99$.

\section{Discussion}

Mao and Zhang (1994) found that 68 ephemeral plant species accounted for $35 \%$ of the total species richness in Gurbantunggut desert. Ephemeral plants form significant synusiae from late March to mid June, the period with the strongest winds in the Junggar Basin. In the Haloxylon community, the productivity of

Table 7

Frequency and relative abundance of genera and several dominant species of AM fungi in soils associated with the roots of ephemeral plants in four desert plant communities in Junggar Basin

\begin{tabular}{lcc}
\hline $\begin{array}{l}\text { AM } \\
\text { fungus }\end{array}$ & $\begin{array}{l}\text { Relative } \\
\text { abundance }(\%)\end{array}$ & $\begin{array}{l}\text { Frequency } \\
(\%)\end{array}$ \\
\hline Acaulospora & 14.0 & 70 \\
Archaeospora & 2.0 & 15 \\
Entrophospora & 0.8 & 15 \\
Glomus & 82.6 & 100 \\
Paraglomus & 0.7 & 10 \\
G. microaggregatum & 16.3 & 30 \\
G. etunicatum & 13.7 & 65 \\
G. claroideum & 13.5 & 70 \\
G. aggregatum & 11.5 & 75 \\
\hline
\end{tabular}




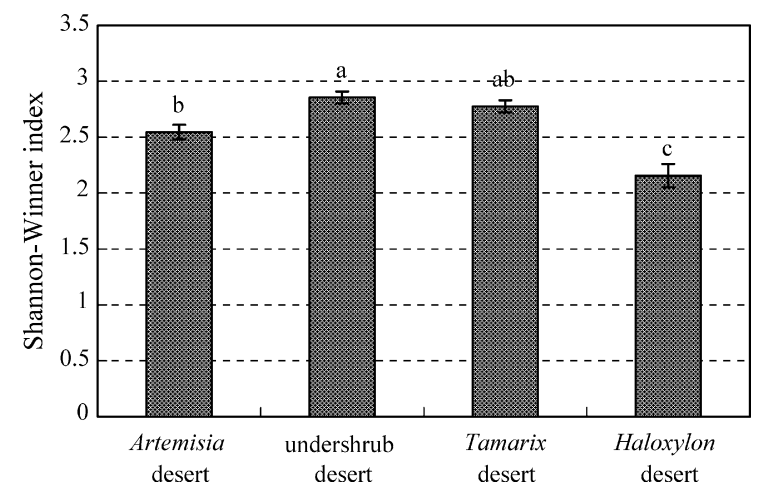

Fig. 2. AM fungal diversity in four desert plant community types.

ephemerals reached $58 \%$ of total plant productivity. The unique temporal and spatial distribution patterns of ephemerals have significance for dune surface stabilization and environmental stability. The period from April to June is the time of the strongest aeolian sand activity in the desert regions of north Xinjiang and corresponds with an ephemeral cover of $>14 \%$, while the total cover of trees, shrubs and herbs during the long vegetative period is $<10 \%$. Hence the ephemerals are the major contributors to the surface stabilization of the dunes (Wang et al., 2003). The habitats of ephemerals are extremely adverse with low nutrient content of the substrate (quicksand), scarcity of water input (annual precipitation of 100-120 mm) and low water content (2-5\%) in the top $30 \mathrm{~cm}$ of the sand beds (Ji et al., 1995; Pan and Huang, 1995). It can be concluded that ephemerals must have unique adaptive mechanisms to the adverse environmental conditions, but there have been few reports of these mechanisms.

Arbuscular mycorrhizal colonization changes with seasonal variation and host plant phenology (He et al., 2002; Bohrer et al., 2004). The highest degree of colonization of the annual ephemerals ( $P$. minuta, $T$. arcuata and $E$. orientale) occurred during the flowering period and one possible explanation is the increasing requirement for nutrients and water at this stage of growth.

In a literature review, Smith and Smith (1997) summarized the types of arbuscular mycorrhiza occurring in different plant taxa, mainly at the family level. They proposed that the different AM structures have specialized roles in the transfer of inorganic nutrients and carbon between the fungal and plant partners, depending on the physiology of the symbiosis between different fungus and plant interfaces. In our investigation, P. minuta (Plantaginaceae), G. sacculifera (Liliaceae) and $T$. arcuat (Fabaceae) were observed to form Arum-type arbuscules. Smith and Smith (1997) showed that the majority of plant species in the Liliaceae formed Arum-type arbuscules. This is the first report of this type of arbuscule in the three ephemeral species. No arbuscules were found in the roots of $T$. kasahstanicus or E. orientale, which had non-septate hyphae and vesicles. Studies have indicated that arbuscules are usually relatively short-lived, with a life span of about one to 2 weeks (Scannerini and Bonfante-Fasolo, 1983; Bonfante-Fasolo, 1984).

AM fungal spore densities tend to be low in arid soils, and zero counts are common (McGee, 1989; Cui and Nobel, 1992; Requena et al., 1996; Siguenza et al., 1996; Carrillo-Garcia et al., 1999). Titus et al. (2002) showed that AM fungal spore densities were generally low $\left(0-0.2\right.$ spores $^{-1}$ soil) in the Mojave Desert ecosystem except for Lycium soils which averaged 1.8 spores $\mathrm{g}^{-1}$ soil. Our mean values of spore density were high compared to the $50-70$ spores per $100 \mathrm{~g}^{-1}$ soil found in the Mojave Desert (Titus et al., 2002), but most of our data (three out of five samples including $P$. minuta, G. sacculifera and T. kasahstanicus) from the Haloxylon community ( $\leq 10$ spores $/ 20 \mathrm{ml}$ soil) in the Gurbantunggut Desert were consistent with the results of Titus et al. (2002).

Identification of AM fungi has traditionally relied on the morphological and developmental characteristics of their large multinucleate spores (Morton and Benny, 1990). In the present study the predominant AM fungi were isolated and identified according to the morphological characteristics of the AM fungal spores. However, we do not know whether all the AM fungi isolated from the soils associated with the roots colonized the ephemerals because other long lifecycle plants occurred in the plant communities. Furthermore, AM fungal diversity differed among the different plant communities. To circumvent this problem, molecular approaches are necessary to define and relate taxa in the Glomeromycota (Redecker et al., 2000; Schüßler et al., 2001; Prosser, 2002).

In the desert ecosystem AM fungi belonging to the genus Glomus were dominant, a result in agreement with previous studies (Lamont, 1982; Tarafdar and Rao, 1990; Pande and Tarafdar, 2004). The predominance of Glomus species in arid conditions may be due to the fact they are the most common AM fungi isolated throughout the world. They may be particularly adaptable to arid conditions because Al-Raddad (1993) reported that the genus Glomus was dominant in arid climates due to its resistance to high soil temperatures. In the present study, G. aggregatum was the most frequent species and G. microaggregatum was the most abundant species. These two species of AM 
fungi are small in size. Similar results indicating a tendency in species composition towards mostly smallspored fungi belonging to the genus Glomus have previously been reported in arid ecosystems (Jacobson, 1997; Stutz et al., 2000). These species may be more adaptable in adjusting patterns of sporulation to environmental stress conditions (Jacobson, 1997). Thus, G. aggregatum and G. microaggregatum may be more adaptable than other AM fungal species under arid conditions.

The AM fungal lifecycle from germination of spores to colonization to host plants, to sporulation is usually about 100-120 days (Smith and Read, 1997). It is well known that ephemerals have short lifecycles, for example 45 days in the case of Gagea sacculifera. We still do not fully understand the significance of the mycorrhizal association to ephemeral plants or how AM fungi can complete their lifecycle after the senescence of the ephemeral host plants. These topics merit further research.

The results of the present study indicate that AM are a common and important component of desert ecosystems and small-spored AM fungi may be better adapted to these ecosystems. This suggests that AM may play an important role in the development and maintenance of desert ephemeral communities. AM therefore cannot be ignored in the management of these communities which are important for grazing and for the supply of materials used in traditional medicines.

\section{Acknowledgements}

This work was supported by the National Natural Science Foundation of China (Grant 30470341) and the Director Foundation of Xinjiang Institute of Ecology and Geography, Chinese Academy of Sciences (Grant 20053039).

\section{References}

Al-Raddad, A.M., 1993. Distribution of different Glomus species in rainfed areas in Jordan. Dirasat-Ser. B: Pure Appl. Sci. 20, 165182.

Biermann, B., Linderman, R.G., 1981. Quantifying vesicular-arbuscular mycorrhizae: a proposed method towards standardization. New Phytol. 87, 63-67.

Bohrer, K.E., Friese, C.F., Amon, J.P., 2004. Seasonal dynamics of arbuscular mycorrhizal fungi in differing wetland habitats. Mycorrhiza $14,329-337$.

Bonfante-Fasolo, P., 1984. Anatomy and morphology of VA mycorrhizae. In: Powell, C.L., Bagyaraj, D.J. (Eds.), VA Mycorrhiza. CRC Press, Boca Raton, FL, USA, pp. 5-33.

Brundrett, M.C., Kendrick, B., 1988. The mycorrhizal status, root anatomy, and phenology of plants in a sugar maple forest. Can. J. Bot. 66, 1153-1173.
Carrillo-Garcia, A., de la Luz, J.L.L., Bashan, Y., Bethlenfalvay, G.J., 1999. Nurse plants, mycorrhizae, and plant establishment in a disturbed area of the Sonoran Desert. Restor. Ecol. 7, 321335.

Cui, M., Nobel, P.S., 1992. Nutrient status, water uptake and gas exchange for three desert succulents infected with mycorrhizal fungi. New Phytol. 122, 643-649.

Dalpé, Y., 1993. Vesicular-arbuscular mycorrhiza. In: Carter, M.R. (Ed.), Soil Sampling and Methods of Analysis. Lewis Publishers, Boca Raton, FL, pp. 287-301.

DeMars, B.G., 1996. Vesicular-arbuscular mycorrhizal status of spring ephemerals in two Ohio forests. Ohio J. Sci. 96, 97-99.

He, X.L., Mouratov, S., Steinberger, Y., 2002. Temporal and spatial dynamics of vesicular-arbuscular mycorrhizal fungi under the canopy of Zygophyllum dumosum Boiss. in the Negev Desert. J. Arid Environ. 52, 379-387.

Jacobson, K.M., 1997. Moisture and substrate stability determine VA mycorrhizal fungal community distribution and structure in an arid grassland. J. Arid Environ. 35, 59-75.

Jeffries, P., Barea, J.M., 2001. Arbuscular mycorrhiza-a key component of sustainable plant-soil ecosystems. In: Hock, B. (Ed.), The Mycota. IX Fungal Associations. Springer-Verlag, Berlin, pp. $95-113$

Ji, F., Fan, Z.L., Zhao, H.G., 1995. Comparison of the physicalchemical characteristics of Aeolian soils in the Taklamakan desert and the Gurbantunggut desert. Arid Zone Res. 11, 21-25.

Koske, R.E., Tessier, B., 1983. A convenient, permanent slide mounting medium. Mycol. Soc. Am. Newslett. 34, 59.

Lamont, B., 1982. Mechanisms for enhancing nutrient uptake in plants, with particular reference to Mediterranean South Africa and Western Australia. Bot. Rev. 48, 597-689.

Mao, Z.M., Zhang, D.M., 1994. The conspectus of ephemeral flora in northern Xinjiang. Arid Zone Res. 11, 1-26.

McGee, P.A., 1989. Variation in propagule numbers of vesiculararbuscular mycorrhizal fungi in a semi-arid soil. Mycol. Res. 92, 28-33.

Morton, J.B., Benny, G.L., 1990. Revised classification of arbuscular mycorrhizal fungi (Zygomycetes): a new order, Glomales, two new suborders, Glomineae and Gigasporineae, and two new families, Acaulosporaceae and Gigasporaceae, with an emendation of Glomaceae. Mycotaxon 37, 471-491.

Morton, J.B., Redecker, D., 2001. Two new families of Glomales, Archaeosporaceae and Paraglomaceae, with two new genera Archaeospora and Paraglomus, based on concordant molecular and morphological characters. Mycologia 93, 181-195.

Pan, W.B., Huang, P.Y., 1995. The study on ecological characteristics of four ephemeral plants. Environ. Protect. Xinjiang 13, 22-27.

Pande, M., Tarafdar, J.C., 2004. Arbuscular mycorrhizal fungal diversity in neem-based agroforestry systems in Rajasthan. Appl. Soil Ecol. 26, 233-241.

Prosser, J.I., 2002. Molecular and functional diversity in soil microorganisms. Plant Soil 244, 9-17.

Redecker, D., Morton, J.B., Bruns, T.D., 2000. Molecular phylogeny of the arbuscular mycorrhizal fungi Glomus sinuosum and Sclerocystis coremioides. Mycologia 92, 282-285.

Requena, N., Jeffries, P., Barea, J.M., 1996. Assessment of natural mycorrhizal potential in a desertified semiarid ecosystem. Appl. Environ. Microbiol. 62, 842-847.

Requena, N., Pérez-Solís, E., Azcón-Aguilar, C., Jeffries, P., Barea, J.M., 2001. Management of indigenous plant-microbe symbioses aids restoration of desertified ecosystems. Appl. Environ. Microbiol. 67, 495-498. 
Scannerini, S., Bonfante-Fasolo, P., 1983. Comparative ultrastructural analysis of mycorrhizal associations. Can. J. Bot. 61, 917-943.

Schreiner, R.P., Mihara, K.L., McDaniel, H., Bethlenfalvay, G.J., 1997. Mycorrhizal fungi influence plant and soil functions and interactions. Plant Soil 188, 199-209.

Schüßler, A., Gehrig, H., Schwarzott, D., Walker, C., 2001. Analysis of partial Glomales SSU rRNA gene sequences: implications for primer design and phylogeny. Mycol. Res. 105, 5-15.

Siguenza, C., Espejel, I., Allen, E.B., 1996. Seasonality of mycorrhizae in coastal sand dunes of Baja California. Mycorrhiza 6, $151-157$.

Smith, F.A., Smith, S.E., 1997. Structural diversity in (vesicular)arbuscular mycorrhizal symbioses. New Phytol. 137, 373-388.

Smith, S.E., Read, D.J., 1997. Mycorrhizal Symbiosis. Academic Press, London, UK, p. 604.

Stutz, J.C., Copeman, R., Martin, C.A., Morton, J.B., 2000. Patterns of species composition and distribution of arbuscular mycorrhizal fungi in arid regions of southwestern North America and Namibia, Africa. Can. J. Bot. 78, 237-245.
Tarafdar, J.C., Rao, A.V., 1990. Survey of Indian arid zone tree species for the occurrence of VAM infection. In: Proceedings of the National Conference on Mycorrhizae. Haryana Agricultural University, Hisar, India, pp. 47-49.

Titus, J.H., Nowak, R.S., Smith, S.D., 2002. Soil resource heterogeneity in the Mojave desert. J. Arid Environ. 52, 269-292.

van der Heijden, M.G.A., Klironomos, J.N., Ursic, M., Moutoglis, P., Streitwolf-Engel, R., Boller, T., Wiemken, A., Sanders, I.R., 1998. Mycorrhizal fungal diversity determines plant biodiversity, ecosystem variability and productivity. Nature 396, 69-72.

Wang, X.Q., Jiang, J., Lei, J.Q., Zhang, W.M., Qian, Y.B., 2003. The distribution of ephemeral vegetation on the longitudinal dune surface and its stabilization significance in the Gurbantunggut Desert. Acta Geogr. Sin. 58, 598-605.

Wang, Y., 1993. Phenological observation of the early spring ephemeral and ephemeroid plant in Xinjiang. Arid Zone Res. 10, 34-39.

Zhang, L.Y., 1985. The preliminary study on ephemeral plants in Mosuowan area of Xinjiang. Acta Phytoecol. Geobot. Sin. 9, 213221. 